\title{
JURISDICTION OF MILITARY COURTS OVER CIVILIAN TERRORISTS IN PAKISTAN: A MISCARRIAGE OF JUSTICE
}

\author{
Muhammad Hassan * \\ Johan Shamsuddin Bin Sabaruddin **
}

\begin{abstract}
The jurisdiction of military courts was extended over alleged terrorists under the Constitution (Twenty-first Amendment) Act, 2015, in order to permanently wipe out terrorism from Pakistan. The amendment was challenged and petitioners contended that jurisdiction of military courts could not be extended over alleged civilian terrorists because of their peculiar nature. Further, the presiding officer of the military court is a member of the executive, which contradicts the principle of judicial independence, an utmost essential element of safeguarding the due process of law. However, the apex court of Pakistan held that terrorism has a direct nexus with the safety and integrity of Pakistan, therefore, the Parliament was competent to expand the jurisdiction of military courts over civilian terrorists in order to secure the country's safety and integrity and thus consistent with the recognized criminal justice system. This research critically analyzes the jurisdiction of military courts over civilian terrorists in accordance with the principle of judicial independence. It also identifies the breach of the fundamental rights of alleged civilian terrorists. This study also determines the capability of existing criminal law statutes of ensuring peace whilst maintaining justice for the accused persons. In order to achieve these objectives, this article adopts a doctrinal research method and carries out an in-depth analysis of the amendments and judgments relating to the issue, while also highlighting the constitutionality of the subject matter. Aside from that, juristic literatures and judgments of the superior courts are also analysed. The study concludes that an independent judicial tribunal is absolutely essential in order to ensure that justice is dispensed to the accused. It is further argued that the scope of the military
\end{abstract}

\footnotetext{
* Ph.D Candidate, Faculty of Law, University of Malaya, Malaysia: Email: hnsial@gmail.com.

** Associate Professor, Faculty of Law, University of Malaya, Malaysia: Email: johans@um.edu.my.
} 
justice system is limited to military personnel, which therefore cannot and should not be expanded over civilian terrorists.

Keywords: The Constitution (Twenty-first Amendment) Act, 2015, military courts, rule of law; independence of judiciary, fundamental rights.

\title{
MENGEMBANGKAN BIDANG KUASA MAHKAMAH KETENTERAAN KEATAS PENGGANAS AWAM DI PAKISTAN: SUATU KETIDAK ADILAN
}

\begin{abstract}
ABSTRAK
Bidangkuasa mahkamah tentera diperluaskan untuk mendakwa pengganas di bawah 'Perlembagaan (Pindaan Kedua Puluh Pertama), 2015' bagi menghapuskan keganasan secara kekal dari Pakistan. Pindaan itu telah dicabar dan pempetisyen yang berpendapat bahawa bidang kuasa mahkamah tentera tidak boleh dilanjutkan ke atas pengganas awam yang didakwa, kerana sifat profesional mereka. Tambahan pula, pegawai pengadilan mahkamah tentera adalah sebahagian daripada eksekutif dan perkara ini bertentangan dengan prinsip kebebasan kehakiman, yang menjadi intipati paling penting untuk menjaga proses hukum yang wajar. Walau bagaimanapun, mahkamah tertinggi Pakistan berpendapat bahawa keganasan mempunyai hubungan langsung dengan keselamatan dan integriti Pakistan, oleh itu Parlimen berhak untuk memperluaskan bidang kuasa mahkamah tentera terhadap pengganas awam untuk memastikan keselamatan dan integriti Pakistan terpelihara. Ini adalah konsisten dengan sistem keadilan jenayah yang diiktiraf. Penyelidikan ini secara kritis menganlisa bidang kuasa mahkamah tentera terhadap pengganas awam mengikut prinsip kebebasan kehakiman dan mengenal pasti sama ada hak asasi mereka yang didakwa telah dilanggar. Kajian ini juga menentukan keupayaan Statut semasa yang berkaitan dengan sistem keadilan jenayah untuk mencapai keamanan dan keadilan semasa. Bagi mencapai matlamat yang dicadangkan, makalah ini menggunakan kaedah penyelidikan doktrin dan menjalankan analisis kritikal mendalam mengenai pindaan dan penghakiman dari perspektif perlembagaan, literatur undang-undang dan penghakiman mahkamah tinggi. Penyelidikan ini menyimpulkan bahawa mahkamah yang bebas adalah sangat penting bagi memberikan keadilan kepada tertuduh. Selanjutnya, skop sistem keadilan ketenteraan adalah terhad dan dengan itu tidak dapat diperluaskan ke atas pengganas awam.
\end{abstract}


Kata Kunci: Perlembagaan (Pindaan Kedua Puluh Pertama) 2015, mahkamah tentera, peraturan perundangan, kemerdekaan kehakiman, hak asasi.

\section{INTRODUCTION}

Pakistan has been facing serious terrorism issues since it became an ally to the US-led war on terrorism. Being an ally, it has also been enduring massive loss of lives and destruction of properties in its own territory. Moreover, on $16^{\text {th }}$ December, 2014, a terrorist attack on the Army Public School in Peshawar, had killed one hundred and forty-five students and teachers. ${ }^{1}$ In response to this tragic incident, the Parliament had amended the Constitution of Pakistan through the Constitution (Twenty-first Amendment) Act, 2015 and expanded the jurisdiction of military courts over the civilian terrorists. The amendment was enacted and came into force to try alleged civilian terrorists before military courts with the aim of permanently wiping out terrorism from Pakistan. The amended Constitution entails that anyone who is allegedly engaged in offences relating to terrorism, insurrection against Pakistan or insurgency by using the name of a sect or religion shall be prosecuted before a military court under the Army Act, 1952, a procedural law for military courts. Additionally, any person who raises arms or allegedly engage in attacks on armed forces or abducts any person for ransom or creates terror and insecurity in Pakistan would be tried before the military court. Furthermore, this amendment also restrains the superior courts from exercising the power of appellate jurisdiction against any of the military courts' verdicts. ${ }^{2}$

Once the Constitutional amendment was enacted and came into force, thirteen petitions were filed before the highest court of Pakistan. The petitioners criticized the amendment and argued that according to the scheme of the Constitution, there is no place for the military court against civilian terrorists and that the establishment of a military court in this regard contradicted the fundamental rights of the accused and went against the principle of judicial independence, a fundamental part of the

\footnotetext{
${ }^{1}$ Sophia Saifi and Greg Botelho, "In Pakistan School Attack, Taliban Terrorists Kill 145, Mostly Children," CNN, December, 17, 2014.

2 The Constitution (Twenty-first Amendment) Act, 2015 (Pakistan).
} 
Constitution. Moreover, they also stated that rule of law, fundamental rights, and independence of judiciary were guaranteed under the Objectives Resolution, 1949, the first significant document which was passed towards framing the first Constitution by the first Constituent Assembly in March 1949. It laid the foundation for the Constitution and provided broad outlines of its structure. ${ }^{3}$

Ultimately, the Supreme Court of Pakistan rejected their pleas and observed that, the trial of civilian terrorist by a military court was consistent with the recognized criminal justice system and in accordance with the principle of judicial independence. Further, this expanded the jurisdiction of a military court to apply to a specific class of people who were known or associated with terrorist organizations. This type of activities of terrorists causes "warlike" situations and posed unprecedented threats to the defence of Pakistan. Therefore, special measures were necessary to be taken in terms of expanding the jurisdiction of military courts over civilian terrorists in order to wipe out terrorism permanently. Moreover, terrorists who did not acknowledge the Constitution must be retaliated against in the same way as they behaved. Further, it was also held that Constitutional protection by way of a Twenty-first Constitutional Amendment had been given to the military court in the interest of the security and integrity of Pakistan. ${ }^{4}$

The first aim of this study is to critically analyse the expanded jurisdiction of military courts over civilian terrorists on the touchstone of the principle of judicial independence and its impact over constitutional guarantees of the accused as incorporated in the Constitution of Pakistan, 1973. Secondly, this study also determines the ability of existing statutes pertaining to the criminal justice system to deal with this issue in order to ensure peace for the public but at the same time ensuring that justice is also awarded to the accused persons.

\footnotetext{
${ }^{3}$ Hamid Khan, Constitutional and Political History of Pakistan, United States of America: Oxford University Press, 2005), 57.

${ }^{4}$ Rawalpindi District Bar Association v. Federation of Pakistan (PLD 2015 SC 401).
} 


\section{COUNTER-TERRORISM MEASURES AND THE RESPONSIBILITY OF A DEMOCRATIC STATE}

Before analysing the Twenty-first Amendment to the Constitution of Pakistan, it is eminent to explain the responsibility of a democratic State when taking counter-terrorism measures. Pakistan is a democratic State and it should take counter-terrorism measures with a proper balance between two principles, i.e., principles relating to the security of the State and principles relating to human dignity and freedom. In a democratic country, the concept of democracy is broader than just the notion of majority rule. Real democracy is not just about the rule of law and legislative supremacy; it is a multidimensional concept. It requires recognition of the power of the majority and the limitations on that power. Although there can be legislative supremacy but there is also the supremacy of values, principles, and respect for human rights. ${ }^{5}$ When there is internal conflict, the formal and substantive elements of a democracy must be balanced to protect the essence of each of these aspects. In this balance, the system must place limits on both legislative supremacy and respect for human rights. Therefore, in maintaining an effective form of democracy, normative supremacy must be given to the Constitution of the State.

The Constitution of Pakistan ensures the integrity of the State and protection of the fundamental rights of the citizen. Therefore, while securing the integrity and defence of the country, the State cannot be granted a license to violate the fundamental rights of its own citizens or even a specific class of people. Since human rights are the core of a substantive democracy, without the protection of human rights, there can be no democracy and no justification for democracy. ${ }^{6}$ In addition, if the State commits act of terror in the same way as the terrorists themselves, then there would be no difference between both actors. A democratic State must act within the framework of the law and uphold the rule of law.

\footnotetext{
${ }^{5}$ Robert Post, "Democracy, Popular Sovereignty, and Judicial Review," Calif. L. Rev., 86 (1998): 429.

${ }^{6}$ Aharon Barak, "A Judge on Judging: The Role of a Supreme Court in a Democracy," Harv. L. Rev., 116 (2002): 19.
} 
It must be admitted that, the protection of human rights is a formidable duty in times of war and terror than in times of peace and security. If the State fails in its role in times of war and terror, it shall not be able to fulfil its role in times of peace and security. It is crystal clear and has been acknowledged that terrorism has devoured thousands of innocent citizens, brave soldiers and policemen in Pakistan but compromising justice for combating terrorism may be a death knell for the value system of the entire nation.

Furthermore, it is true that the Constitutional and legal measures with regard to amending the Constitution have been adopted by the people of Pakistan through their chosen representatives in the Parliament. But it has also witnessed that some parliamentarians have called it a bitter pill, a cup of poison and a dark day for democratic Constitutional dispensation while others have publicly expressed shame and disgust over their own conduct. ${ }^{7}$ This is because they were probably influenced by Article 63-A (I)(b)(III) of the Constitution of Pakistan, 1973 against their own free consent by their respective political leadership while casting their votes in order to amend the Constitution. Besides, the war against terrorism is considered as a reaction from a law-abiding State against law breakers. It is, therefore, not merely a war of the State against its enemies; it is also a war of the law against its enemies. Therefore, a democratic State has to recognize the fundamental rights of the accused while securing its own integrity. Hence, every citizen, including alleged terrorists should have the equal opportunity and right to approach the independent courts without any discrimination. ${ }^{8}$

\section{JUDICIAL INDEPENDENCE AND THE EXPANSION OF THE JURISDICTION OF MILITARY COURTS OVER CIVILIAN TERRORISTS IN PAKISTAN}

There are dual aspects to the principle of judicial independence, namely the individual aspect and the institutional aspect. First, with respect to individual independence, a judicial officer must be secured from any threat of reprisal. Otherwise, he may not be able to dispense justice with

7 "Raza Rabbani in tears: 'Ashamed to vote against conscience," Dawn, January, 6, 2015.

${ }^{8}$ Government of Baluchistan v. Azizullah Memon (PLD 1993 SC 341). 
impartiality. Secondly, with regards to the issue of institutional independence, the main concern would be on service-related matters including the appointment, salary or promotion and accountability of the judges, which must be protected from any external influence i.e. from any other organs of the State. ${ }^{9}$ Such judicial officers protected from external pressure to fairly administer justice and be perceived to be doing so. When threats come from other branches of the government, this undermines the impartiality of the judiciary. ${ }^{10}$

Additionally, this concept of judicial independence guarantees due process of law and it also confers the strength to the judicial officer in terms of making a decision based on merits over any matter. The rule of law establishes the confidence of the public at large over the judicial system of the country. Therefore, any attempts which causes a dent upon the confidence of the people regarding the judicial system must be strongly discountenanced. ${ }^{11}$ Even the framers of the United States' Constitution in the seventeenth-century also acknowledged the importance of effective and impartial functioning of the judiciary that it must not be subjected or dominated from the rest of the organs of the State. In this regard, the United States' Constitution ensured the classification of three organs of the government with their principal Constitutional domains, namely the legislature, the executive and the judiciary. Further, Alexander Hamilton had emphasized the importance of impartiality when he wrote that a "steady, upright, and impartial administration of the laws" is essential because "no man can be sure that he may not be tomorrow the victim of a spirit of injustice, by which he may be the gainer today".

Moreover, judges must be entrusted with the ultimate authority of deciding pertinent issues relating to the protection of civil liberties, lives, duties and properties of the people. The judges can never win the respect and confidence of the parties if they are subject to any influences.

9 Sandra Day O'Connor, "Judicial Accountability Must Safeguard, Not Threaten, Judicial Independence: An Introduction," Denver University Law Review 86, no. 1 (2008): 1-6.

${ }^{10}$ P.H. Russell, and D.M. O'Brien, Judicial Independence in the Age of Democracy: Critical Perspectives from around the World, (University Press of Virginia, 2001).

${ }^{11}$ Attorney-General v. B.B.C. [1981] A.C. 303, 313. 
Whenever a judicial officer makes any decision for his personal benefits, or to avoid censure or to curry favour, that very act ultimately denigrates impartiality of the judiciary and rule of law. ${ }^{12}$ Additionally, an independent judicial organ, which is not subservient to the executive, can be a surety for upholding the rule of law and Constitutional guarantees incorporated in the Constitution. ${ }^{13}$

Similar to the federal arrangement in the United States, the Constitution of Pakistan, 1973 also divides organs of the government into three parts along with their independent functions i.e., the legislature, the executive and the judiciary. None of these three organs are dependent over the other or claim superiority over the other. ${ }^{14}$ It is also to be noted that the independence of the judiciary is one of the salient features of the Constitution of Pakistan, which cannot be denigrated. This concept of independence was incorporated for the first time in the Constitutional history of Pakistan under Objectives Resolution, 1949, a first significant step, which was taken by the founders of Pakistan towards framing the first Constitution. The same was adopted as the preamble of the Constitution of Pakistan wherein it was stated that the independence of the judiciary shall be secured. ${ }^{15}$ Now the same preamble has become a substantial part of the Constitution under Article 2-A of the Constitution of Pakistan, 1973. Therefore, an independent judiciary has become an important organ of the State and hallmark within the Constitutional sphere. Further, the Constitutional framework relating to the judiciary does not permit the establishment of a parallel system of any court or tribunal, whose decision is not subject to judicial review, administrative control and supervision of the respective High Courts as enunciated in Articles $175^{16}, 202^{17}$ and $203^{18}$ of the Constitution of Pakistan. In this context, performing a judicial function by another organ of the state

\footnotetext{
12 O'Connor.

13 Woodrow Wilson, Constitutional Government in the United States, (Routledge, 2017).

${ }^{14}$ Govt of Baluchistan v. Azizullah Memon (PLD 1993 SC 341).

${ }^{15}$ Preamble, Constitution of Pakistan 1973.

${ }^{16}$ Establishment and Jurisdiction of Courts, Constitution of Pakistan 1973.

${ }^{17}$ Rules of Procedure, Constitution of Pakistan 1973.

${ }^{18}$ High Court to Superintendent Subordinate Courts, Constitution of Pakistan 1973.
} 
would be a violation of the principle of trichotomy of power and due process of law over the accused. ${ }^{19}$

The above argument is due to the fact that military courts are being controlled and supervised by the military, a branch of the executive and thus fails to meet the qualification, which the Constitution of Pakistan has set in order to ensure the independence of the judiciary. An independent judiciary is a pre-requisite for preserving the Constitutional guarantees of the accused. The prosecution and presiding officers of the military court belong to the military, a branch of the executive and thus it would be in conflict if they were to adjudicate the matter on their own cause. In addition, the military justice system is treated as a parallel system of justice operated by the executive branch and quite dissimilar from ordinary criminal justice systems. It uses and applies its own special laws and procedures for the purpose of promoting justice sternly in order to maintain discipline and good order in the Armed Forces.

In addition, it also promotes efficiency and effectiveness in the military establishment for the purpose of strengthening national security. The apex court of the United States has described specialized professional agency comprising military personnel as different by nature from a society comprising of civilians. ${ }^{20}$ The same view has also been endorsed in another case where a military society has been set apart from a civilian society. In this context, military law is a distinct jurisprudence, which exists separately from the ordinary law of the land, which administers the law on civilians. ${ }^{21}$ Further, the judge of a court martial is not selected randomly but picked and chosen by the convening authorities of the court martial upon their own wishes for quick determination. ${ }^{22}$

An additional distinguishing feature is the use of special and speedy regulations in relation to military discipline in order to ensure that the military organization functions effectively. On the other hand, the same

${ }^{19}$ Sh. Riaz Ul Haq v. Federation of Pakistan (PLD 2013 SC 501).

${ }^{20}$ Parker v. Levy, 417 U.S. 733, 743 (1974).

${ }^{21}$ Burns v. Wilson, 346 U.S. 137, 140 (1953).

22 James B Roan and Cynthia Buxton. "The American Military Justice System in the New Millenium." Air Force Law Review 52 (2002): 185-211. 
strict discipline and regulations are unacceptable in civilian society. ${ }^{23}$ Additionally, the military justice system is developed as a separate legal system under the system of command and control because military units are often insulated from civilians. ${ }^{24}$ It is significant to mention here that the ultimate goals of both the justice systems are different. Thus, if ordinary courts applied the same traditional military rules over civilians in the same manner as applied by the military courts over military personnel, such practice will ultimately dilute its own utility and efficacy, which is exercised inside the military units in order to maintain discipline, command, and control over the forces. ${ }^{25}$

It is further submitted that, even the service members and retired army personnel do not fall in the category of the military forces and could not be tried by the military courts against any offense even if committed during military service. Further, it was also ruled that no trial could be initiated against such a person who has already terminated all his connections with the army. The jurisdiction of the military courts only applies to active serviceman of the army who is connected to and serving in the armed forces. ${ }^{26}$ Furthermore, the Inter-American Court of Human Rights also held that, the application of military justice must be strictly applied upon active-duty military members only and that if during proceedings the accused retired from the army, he could no longer be tried by the military courts. ${ }^{27}$ In addition, the United Nation states that the military justice system, which took cognizance of service members or even retired army personnel did not comply with contemporary international standards of criminal justice system. ${ }^{28}$

${ }^{23}$ Vladeck, Stephen I., "Military Courts and Article III." The Georgetown Law Journal 103 (2014): 933-1001; Chappell v. Wallace, 462 U.S. 296, 300 (1983). ${ }^{24}$ Edward F. Sherman, "Military Justice without Military Control," Yale Law Journal 82 (1972): 1398.

${ }^{25}$ Edward F. Sherman, "The Civilization of Military Law," Maine Law Review 22 (1970): 3-103.

${ }^{26}$ United States ex rel. Toth v. Quarles, 350 U.S. 11. (1955).

${ }^{27}$ Eugene R. Fidell, "Criminal Prosecution of Civilian Contractors by Military Courts," SouthTexas Law Review 50 (2008): 845-57.

28 Commission on Human Rights, Draft UN Principles Governing the Administration of Justice Through Military Tribunals, E/CN.4/2006/58, January, 13, 2006. The Supreme Court abandoned the service-connection 
Hence, anti-terrorism measures should be consistent with the recognized criminal justice system and the State's obligations under international law. Due process is a right, which democratic States have always considered as a central part for the administration of criminal justice. In addition, Article 14 of the International Covenant on Civil and Political Rights, 1966 (ICCPR) ${ }^{29}$ (of which Pakistan is a signatory State since 2010) also provides that everyone, shall be entitled to be tried fairly, in a public hearing by an independent and impartial tribunal. ${ }^{30} \mathrm{It}$ also provides equality before the courts and tribunals, side by side with Article 26, which provides equality before the law. This is a fundamental protection of the right to a fair trial, encompassing trial proceedings, ensuring not only equal access to the court but also guaranteeing a correct application of the law by an independent judiciary. It also assures that every person appearing before the court of law is not discriminated on account of gender, race or even the gravity of the offense. It also prohibits separate special courts based on the gravity of the offence, and it problematizes the admissibility of special courts such as military courts and the potentiality of trying civilians before these courts. ${ }^{31}$ Although, Article 14 deals with the right to fair trial, it is a derogable right, in case of national emergency under Article 4(2) of ICCPR. However, the same Article 14 was proposed by optional protocol to be included as one of the non-derogable rights under Article 4(2) of ICCPR. ${ }^{32}$

Currently, Pakistan is not in a situation that would allow for such derogation since Pakistan is not under martial law nor is there a state of

requirement in Solorio v United States, 483 U.S. 435 (1987). The decision overruled O'Callahan v. Parker, 395 U.S. 258 (1969).

${ }^{29}$ A nationwide accepted human rights document of which Pakistan is also signatory state since 2010 .

${ }^{30}$ Article 14, International Covenant on Civil and Political Rights 1966.

${ }^{31}$ M. Nowak, U.N. Covenant on Civil and Political Rights: Ccpr Commentary, (N.P. Engel, 1993).

${ }^{32}$ Draft Optional Protocol to the ICCPR, Aiming at Guaranteeing Under All Circumstances the Right to a Fair Trial and a Remedy, Annex I, in: "The Administration of Justice and the Human Rights of Detainees, The Right to a Fair Trial: Current Recognition and Measures Necessary for its Strengthening," Final Report, Commission on Human Rights, Sub- Commission on Prevention of Discrimination and Protection of Minorities, 46th Session, E/CN.4/Sub.2/1994/24, June 3, 1994, at 59-62. 
emergency. As such, the civilian courts are doing their judicial business properly although there are certain emergency provisions incorporated in the Constitution of Pakistan which can only be imposed with a declaration by the President of Pakistan on account of a real threat of war, external aggression or internal disturbance. During the proclamation of emergency, certain alienable fundamental rights could be suspended but only for a certain period. Even then it is subject to certain prerequisites. For example, there must be prior approval of the parliament but not in such way to empower the military courts to try the citizen who is allegedly involved in a terrorism-related offence. Moreover, it is also worth mentioning that in spite of the state of emergency, the right to fair trial under Article 10-A of the Constitution of Pakistan cannot be suspended at all. ${ }^{33}$ Besides, in the current scenario, there are two types of terrorists. Firstly, those who could be tried either by military courts or Anti-Terrorism Courts established under the Twenty-first Constitutional amendment and Anti-Terrorism Act, 1997 respectively. The second type of terrorists, are those who are allegedly engaged in terrorism-related offences like insurrection of war or insurgency on account of sectarianism or religion. They shall be tried under the military courts. Others are persons accused of terrorism-related offences as defined in the Anti-Terrorism Act, 1997, who would be tried under Anti-Terrorism Courts, which is a negation of 'equality before law' and 'equality of citizen', as enunciated under Article 4 and 25 of the Constitution of Pakistan respectively. ${ }^{34}$ Previously both types of alleged terrorists were triable by the Anti-Terrorism Courts established under the AntiTerrorism Act, 1997.

Thus, in order to bifurcate those accused to have committed terrorism and are to be tried by Anti-Terrorism Courts under the Anti-Terrorism Act, 1997, a separate sub-category of those using the name of religion or sect is not sufficiently precise and is also not reasonably classified. If the State invokes human rights to justify its forceful action in response to terrorism then it must be accepted that securing human rights of all citizens is equally a binding constraint and also applies over the State's action.

\footnotetext{
${ }^{33}$ Article 232-237 of the Constitution of Islamic Republic of Pakistan 1973.

${ }^{34}$ Tom J. Farer, "The Two Faces of Terror," American Journal of International Law 101, no. 2 (2007): 363-81.
} 
Additionally, it is pertinent to mention here that military courts were previously constituted in Pakistan to try civilians in 1998 when the situation was gradually deteriorating and sectarian killing was allegedly taking place across the country. In response, to control the situation, military courts were established under the "Pakistan Armed Forces (Acting in Aid of Civil Power) Ordinance, 1998."35 This Ordinance allowed military courts to try civilians, charged with offenses mentioned in the Schedule of the Ordinance, 1998. However, the same Ordinance was challenged before the Supreme Court on account of the violations on the concepts of judicial independence, rule of law and fundamental rights enshrined in chapter one and Article $175,{ }^{36} 203^{37}$ of the Constitution.

Finally, the apex court of Pakistan observed that the Constitutional guarantees and military courts cannot be gathered in accordance with the scheme of the Constitution of Pakistan. The role of the Armed Forces while acting "in aid of civil power", does not exercise the right of adjudication either directly or indirectly as established under Article 175(1) of the Constitution of Pakistan 1973. This is the sole jurisdiction of the judicial organ of the State which is in accordance with the scheme of the Constitution and it is eminent in its preamble which has now become a substantive part under Article 2-A, which declares that the principle of judicial independence and fundamental rights shall be guaranteed. Thus, it is well settled law that an impartial judiciary means every judge should be free to determine and decide matters placed before him without any undue influences, inducements or pressures.

Otherwise, the purpose of an uninfluenced judiciary, which is a pivotal organ of any State, cannot be achieved if the fundamental right of access to fair justice become diluted. The apex court further held that establishing military courts, which are being administered by the army, a part of the executive, to decide cases and adjudicate rights, without control and supervision of the judicial organ can hardly meet the scheme of the Constitution. Therefore, any findings of a tribunal or court which is not subject to judicial review and administrative control of the superior

35 Pakistan Armed Forces (Acting in Aid of Civil Power) Ordinance 1998 (Ordinance XII of 1998).

${ }^{36}$ Establishment and Jurisdiction of the Courts, Constitution of Pakistan 1973.

${ }^{37}$ High Court to Superintendent Subordinate Courts, Constitution of Pakistan 1973. 
courts fails to comply with the principle of judicial independence. Hence, the impugned Ordinance is a violation of the principle of judicial independence and Constitutional guarantees and liable to be declared unconstitutional. $^{38}$

However, the Armed Forces can be called upon by the Federal Government under Article 245 of the Constitution to defend Pakistan against external aggressions or threats of war but the actions of the Armed Forces must be germane and only to restore peace and tranquillity. Having said that, it is not meant to confer them judicial power, which is a violation of the principle of judicial independence enunciated in Article 175(1) of the Constitution. They can certainly apprehend those culprits who disturb or threaten to disturb peace and tranquillity, but these accused persons can only be tried by ordinary civil courts.

In view of the above discussions, if military courts established under the 1998 Ordinance could be declared null and void by the Supreme Court of Pakistan due to the violation of the concept of the independence of judiciary, then allowing martial courts under the Twenty-first Amendment to the Constitution is in fact a violation of the core principles enshrined in the Constitution itself. Therefore, the purpose of eradicating terrorism and the establishment of military courts is not constitutionally justified as the offences can be tried by special courts already established under the Anti-Terrorism Act, 1997 for the same purpose, i.e. to ensure peace, order and fair justice. The assurance of providing fair justice to the accused and upholding the rule of law is directly connected with an independent judiciary. Indeed, a strong and independent judiciary that fairly and expeditiously adjudicates terrorism or national security offenses is necessary for public confidence and it is an effective deterrent to terrorism and marks the distinction between a civilized society and a state of anarchy. Further, it is crystal clear on the face of Preamble and Article 2-A that rule of law, fundamental rights, independence of the judiciary, civil liberties as enunciated in the Constitution are the foundations on which the Constitutional structure has been based. A parallel judicial system in the form of military courts under the behest of the army, a branch of the executive can be the modes for blocking the

${ }^{38}$ Sh. Liaqat Hussain and others v. Federation of Pakistan (PLD 1999 SC 504). 
road of access to fair justice.. ${ }^{39}$ The Constitution can be amended by the central legislative body but it must be done by also keeping in view of the basic structure and scheme of the Constitution.

\section{THE RIGHTS OF THE ACCUSED: THE CONSTITUTION OF PAKISTAN, 1973}

There are various fundamental rights of the accused that must be respected. These rights are enshrined in the Constitution of Pakistan, which secure them from arbitrary and abuse power by the State. It is the beauty of the law that it seeks to do justice for everyone including accused persons, without any prejudice and bias. After all, the accused is innocent until proven guilty. Therefore, the Constitution of Pakistan, 1973 also guarantees the fundamental rights of the accused and preserves his fundamental rights while he is being tried.

In the same context, it has been observed by the apex court of Pakistan that while interpreting the Constitutional provisions regarding Constitutional guarantees, the approach of the court should be dynamic progressive and liberal by keeping in view the rights of the accused. This is found in the Objectives Resolution, $1949 .{ }^{40}$ It has further been observed in another case that the Constitution is to be interpreted in a liberal and beneficial manner by keeping in view the spirit behind the fundamental rights guaranteed by the Constitution. ${ }^{41}$ Further, the right of access to fair justice also lies within such Constitutional guarantees, which states that accused persons shall have a right to be tried fairly ${ }^{42}$ and this could not be guaranteed without an independent judiciary. ${ }^{43}$ There are various fundamental rights of the civilian accused incorporated in the Constitution of Pakistan discussed hereunder, which is in danger of being violated if they were to be tried by the military courts.

\footnotetext{
${ }^{39}$ Sh. Liaqat Hussain and others v. Federation of Pakistan (PLD 1999 SC 504). ${ }^{40}$ Objectives Resolution, 1949 is foundational document towards the framing of the Constitution of Pakistan, given by the First Constituent Assembly.

${ }^{41}$ Benazir Bhutto v. President of Pakistan (PLD 1998 SC 388).

${ }^{42}$ In the case of Mushtaq Ahmed Mohal v. Hon'ble Lahore High Court (1997 SCMR 1043).

${ }^{43}$ Shaukat Aziz Siddiqui v. Federation of Pakistan (PLD 2018 SC 538).
} 


\section{Individuals to be dealt with in accordance with law (Article 04)}

The Constitution of Pakistan 1973 states that every citizen shall have inalienable Constitutional right to be protected and treated in accordance with law. In this regard, no action would be taken by the State, which may be detrimental to the life, body, liberty, reputation or property of the accused, save in accordance with law. ${ }^{44}$

Article 4 of the Constitution of Pakistan, 1973 in terms of the rule of law, is the bedrock of the Constitution of Pakistan. Similarly, the court has a constitutional responsibility to enforce the rule of law in the true spirit of safeguarding the Constitution. For this purpose, the courts of the country in their various judgments upheld the rule of law, which includes that every citizen must be dealt with in accordance with applicable law of the land. Whoever is triable under the ordinary criminal laws but is heard under special laws would be considered as a violation of the command of the Constitution. ${ }^{45}$ Further, it was also stated by the court that every citizen within the territory of the State has the right to enjoy the protection of the law and to be treated in accordance with law and in this regards, no action could be taken which is detrimental to life and liberty of the individual save in accordance with law. ${ }^{46}$ Moreover, it was also observed that it is an inalienable right and must be read with the "right to fair trial" enshrined in Article 10-A of the Constitution of Pakistan. ${ }^{47}$ Furthermore, it was also ruled that judicial independence, rule of law, democracy, and federalism, were salient features of the Constitution and need to be preserved. ${ }^{48}$

Now the question arises, what does it mean by the rule of law or in accordance with law? According to Barber, it means to be governed by law, rather than by men ${ }^{49}$ and it is a prerequisite of making or amending any law as the case may be, that the State must preserve the fundamental

${ }^{44}$ Article 4, the Constitution of Islamic Republic of Pakistan 1973.

${ }^{45}$ Province of Punjab v. Muhammad Rafique (PLD 2018 SC 178).

${ }^{46}$ Yasir v. The State and Others (2018 YLR 379); Zia Ur Rehman v. The State (2018 YLR 1810).

${ }^{47}$ Muhammad Asif v. Government of Sindh (2017 PLC (C.S) 42); Gulfaraz Khan v. Government of KPK (PLD 2017 Peshawar 23).

${ }^{48}$ Rawalpindi Bar Association v. Federation of Pakistan (PLD 2015 SC 401).

${ }^{49}$ N. W. Barber, "Must Legalistic Conceptions of the Rule of Law have a social dimension?" Ratio Juris, 17(4), (2004): 474-488. 
rights of individuals which uphold their dignities. In addition, the rule of law is a protective net over the rights of citizens, which preserve them from arbitrary and abusive use of powers by the State's organs and it has become a sacred object for those who criticize states against its abusive practices. Furthermore, it is a beacon light for human rights' defenders and those who desire better entrusted legal systems in the State. ${ }^{50}$

In this regard, Viljoen ${ }^{51}$ states that there can be no rule of law if there is no access to the basic sources of law and additionally it is indeed the opposite to the rule of absolute power and supremacy of law over the will of the individuals. ${ }^{52}$ Moreover, as quoted by Dr. Saroja \& Dr. Johan Shamsuddin in the case of Church of Scientology $v$. Woodward in which it was ruled that the powers conferred to the judicial organ in terms of judicial checks are indeed the enforcement of the rule of law against ultra vires acts of the executive. If it exceeds, it must be prevented as the functions assigned to the executive and should be done in the interest of the individuals and their protection accordingly. ${ }^{53}$ Thus, it indicates that the implementation of the rule of law is dependent on the existence of an independent judiciary which is a key to upholding it in a free society. Therefore, fundamental rights can only be secured if the judge appears to be free and independent to make impartial decisions in the light of facts and the law. ${ }^{54}$

According to Joseph Raz, a constitutional theorist, he states that the principle of the rule of law guides the individual's behavior and minimizes the threat, which may be caused from the exercise of the discretionary power of an executive in an arbitrary fashion. Not only that,

50 Nicolas Hachez and Jan Wouters, "Promoting the Rule of Law: A Benchmarks Approach," Leuven Centre for Global Governance Studies, (2013): 1-27.

${ }^{51}$ CEO of LexisNexis Pacific.

52 Denise Meyerson, "The Rule of Law and the Separation of Powers," Macquarie Law Journal, 4, (2004): 1-6.

${ }^{53}$ Saroja Dhanapal and Johan Shamsuddin Sabaruddin, "Rule of Law: An Initial Analysis of Security Offences (Special Measures) Act (Sosma) 2012" IIUM Law Journal 23, no. 1 (2015): 1-29; Church of Scientology v. Woodward [1982] HCA 78; 154 CLR 25.

54 Daniel C. Préfontaine and Joanne Lee, "The Rule of Law and the Independence of the Judiciary," Review Quebecoise De Droit International 11 (1998): 163-86. 
he also laid down certain qualifications or prerequisites, which must be followed by the legislative body before making or amending any law. Firstly, every law must have a prospective effect rather than retrospective effect and it requires the State to treat the subjects of law as equals and protect their individual liberties. ${ }^{55}$ Secondly, the principle of natural justice needs to also be observed, particularly those that relate to the rule of law and in this regard the principle of judicial independence is the cornerstone, which must be guaranteed and everyone should have access to the court of law against any grievances. ${ }^{56}$

Furthermore, in 2009 the doctrine of the rule of law was described substantively by the Council of International Bar Association (IBA). According to the Council, it includes an independent and impartial tribunal, presumption of innocence in favor of the accused, the right to a fair and public trial without undue delay, a rational and proportionate approach to punishment, a strong and independent legal profession, equal treatment before the law and strict protection of confidential communications between lawyer and client which are all fundamental principles of the rule of law and correlated with each other. Moreover, arbitrary arrests, secret trials and unlimited detention without trial are all unacceptable. This is because the rule of law is the foundation of a civilized and democratic society, which establishes a transparent process for the administration of justice and should be accessible equally to all. ${ }^{57}$ Whenever a law enacted by the government subverts the rule of law, the courts shall have judicial competence to nullify it. ${ }^{58}$

\section{The Right to Life (Article 09)}

The Constitution of Pakistan 1973 provides the 'right to life' to every citizen under Article 09 which states that nobody shall be deprived from his life except in accordance with law and prohibits arbitrary deprivation

\footnotetext{
55 P. Gowder, "The Rule of Law and Equality," Law and Philosophy, 32(5), (2013): 565-618.

56 Joseph Raz, "The Rule of Law and Its Virtue," The Rule of Law and the Separation of Powers, (Routledge, 2017), 77-94.

${ }^{57}$ Resolution of the Council of the International Bar Association of October 8, 2009, on the Commentary on Rule of Law Resolution (2005).

58 Jackson and others v. Her Majesty's Attorney General [2005] UKHL 56.
} 
of life. ${ }^{59}$ Indeed, the concept of life and liberty of the human body was firstly introduced in Magna Carta 1215. It stated that everyone is free by birth and no one can be apprehended without due process of law. ${ }^{60}$ By the end of the eighteenth century, liberty had become one of the three highest values to be defended, being coupled with equality and fraternity in the French Revolution together with life and property or the pursuit of happiness. ${ }^{61}$

Articles 4 and 9 of the Constitution of Pakistan indirectly declare that the protection of life and liberty is not only meant for the citizen of Pakistan but also for those who are temporarily staying in Pakistan. However, there is a remarkable distinction between these two mentioned Articles of the Constitution. The former gives more basic rights than the latter because in the case of the proclamation of Emergency, the operation of Article 9 may be suspended but Article 4 remains in full force even during Emergency.

The word 'life' in Article 9 includes the right to live with dignity as guaranteed, a right to be treated by keeping in view the rule of law, a right to enjoy protection from any trespassing act by the executive on the right of privacy and liberty and right of access to justice, which are inherent in the right to life. Moreover, the apex court further ruled that access to justice would be a mere travesty and illusion in the absence of an independent judiciary, which ensures fairness. Therefore, the demand for a judiciary, which is free from the executive, is indispensable and a constitutional safeguard to the right of access to justice. ${ }^{62}$ On the other hand, the establishment of a military court which may also award death sentences to a specific class of alleged terrorists under the constitutional amendment militates against the right to life as well as the concept of independence of the judiciary which is one of the salient features of the Constitution enunciated in Chapter One of Part VII of the Constitution of

${ }^{59}$ Article 9, the Constitution of Islamic Republic of Pakistan 1973.

${ }^{60}$ Ch. 26 in the version confirmed by King Edward 1 in 1297; 6 Halsbury's Statute (3rd ed.) 401.

${ }^{61}$ Paul Sieghart, The International Law of Human Rights, (Oxford University Press, 1983).

${ }^{62}$ Chief Justice of Pakistan Iftikhar Muhammad Chaudhry v. President of Pakistan (PLD 2010 SC 61). 
Pakistan. Although liberty is not an absolute right, but its deprivation should be through the due process of law. ${ }^{63}$

\section{The Right to Fair Trial (Article 10-A)}

Most of the constitutions of democratic countries provides "right to fair trial" to the accused in varying degrees. ${ }^{64}$ The same right is newly inserted in the name of Article 10-A in the Constitution of Pakistan under the Constitution (Eighteen Amendment) Act, 2010. It is central to the protection of human rights not only as a right in itself but because excluding this one right would affect all others rights. ${ }^{65}$ The right of the accused to avail justice includes the right to be tried fairly before an impartial and independent court or tribunal. ${ }^{66}$ It is worth mentioning here that the Supreme Court (SC) ruled that the legislature cannot enact such laws which may suspend the right to approach the courts of law, because the denial of this right is also an infringement of other fundamental rights. ${ }^{67}$ Therefore, it is the right of the parties to be tried, uninfluenced or unbiased, by the court and it is also an established principle that the court should not prejudice any party. Such a right is available not only to criminal charges but also to civil rights and obligations. ${ }^{68}$

It is to be noted that Article 10 itself does not expressly clarify the right to fair trial and its scope. In this regard, the International Covenants on Civil and Political Rights (ICCPR) and the European Convention on Human Rights (ECHR) may be helpful in exploring salient features that constitutes a fair trial. Article 14 and Article 6 of ICCPR \& ECHR respectively, state that due process of law includes hearing in open court, both in criminal and civil cases, before an impartial and independent

\footnotetext{
${ }^{63}$ Shaukat Mahmood and Nadeem Shaukat, The Constitution of the Islamic Republic of Pakistan, 1973, (Legal Research Centre, 2006), 63-64.

${ }^{64}$ M Cherif Bassiouni, "Human Rights in the Context of Criminal Justice: Identifying International Procedural Protections and Equivalent Protections in National Constitutions," Duke Journal Comparative \& International Law 3, no. 2 (1992): 235.

${ }^{65}$ David Robertson, A Dictionary of Human Rights, (Routledge, 2003).

${ }^{66}$ Sharaf Faridi v. Federation of Pakistan (PLD 1989 Kar. 404).

${ }^{67}$ Government of Baluchistan v. Azizullah Memon (PLD 1993 SC 341)

${ }^{68}$ Matloob Hussain v. The State 2005 MLD 1101.
} 
judicial body, without any delay and judgment shall be announced in an open court of law. In certain cases, limitations may be imposed against third parties in terms of prevention from attending all or part of a trial. Further, it also includes that over the entire trial, the accused shall be presumed innocent unless proven guilty beyond any reasonable doubt. Whereas, according to the Twenty-first Amendment, the accused is presumed guilty unless proven innocent, which clearly violates the due process of law.

Furthermore, the apex court of Pakistan also ruled that the right to fair trial is a long-recognized right, which now has become a substantial clause of the Constitution. The court further added that Article 10-A, had been raised to a higher pedestal but the legislative body left the term 'fair trial' unexplained. Nevertheless, a universally accepted definition, describes that it includes, the "right to conduct fair hearing by an impartial competent forum by keeping in mind the principle of natural justice and justice should not only be done but be seen to be done, and it can only be assured by the independent judiciary. ${ }^{, 69}$ Indeed, Article 10-A is intrinsically linked to other fundamental rights guaranteed by the Constitution and violation of a fair trial would also be a violation of other connected fundamental rights. $^{70}$

In addition, there is a link between an independent tribunal and the due process of law for a better assurance of the rights of the accused. It must also be noted that the deprivation of the due process of law in itself is not a right, which can be used as an attacking device on the substance of the verdict of the court but a guarantee for safe and efficient court proceedings. ${ }^{71}$ Courts, when hearing criminal cases, must ensure that the accused persons are awarded every opportunity to defend himself with surety, that his right to fair trial is not being violated as that right is

${ }^{69}$ Malik Riaz Hussain v. Dr Arsalan Iftikhar (PLD 2012 SC 664)

${ }^{70}$ Hina Hafeezullah Ishaq, "The Right to Fair Trial: Better Late Than Never," LUMS Law Journal 1, no. 1 (2014): 96-107.

${ }^{71}$ Sarah Joseph and Melissa Castan, The International Covenant on Civil and Political Rights: Cases, Materials, and Commentary, (Oxford University Press, 2013), 408 
"aimed at ensuring proper administration of justice". 72 It is the responsibility of adjudicating authority to ensure that the trial has been conducted fairly, in accordance with the prescribed criminal justice system. ${ }^{73}$ A court that does not ensure a fair proceeding would defeat its character regarding impartiality, as it is an organ of which the sole purpose is to dispense justice fairly and judiciously ${ }^{74}$ as well as to protect the human rights. ${ }^{75}$

\section{THE ABILITY OF THE EXISTING CRIMINAL JUSTICE SYSTEM IN RESPONDING TO TERRORISM IN PAKISTAN}

The Government of Pakistan has stated to the Supreme Court that the present criminal justice system is incapable of maintaining peace in the country. Under the current scheme, despite many arrests, there are very few convictions, that has resulted in the country being in the grip of terrorism. This is why the Government contends that military court is the only effective "weapon" to fight the rapidly spreading menace of terrorism. There are also arguments that claim that it can act as a deterrent to acts of terrorism more efficiently and help to permanently wipe out terrorists from Pakistan. They believe that extraordinary measures are necessary to be taken in the interest and integrity of Pakistan against certain offenses relating to terrorism, waging of war or insurrection against Pakistan by any terrorist or terrorist group, or an armed group, using the name of religion or a sect.

Nonetheless, it is submitted that the above argument stands belied by the data collected, which shows that the criminals were let off due to lack of evidence, lack of provision of proper security to the judges, witnesses

\footnotetext{
${ }^{72}$ Report of the Human Rights Committee, General Assembly Official Records: Thirty-Ninth Session, Supplement No.40 (A/39/40), General Comment13/21, 143.

${ }^{73}$ Christoph Johannes Maria Safferling, Towards an International Criminal Procedure, (Oxford University Press, 2001), 21-33

${ }^{74}$ Bahma Sivasubramaniam, "The Right of an Accused to a Fair Trial: The Independence of the Impartiality of the International Criminal Courts," (PhD diss., Durham University, 2013), 18-20

${ }^{75}$ David Harris, "The Right to a Fair Trial in Criminal Proceedings as a Human Right," International \& Comparative Law Quarterly 16, no. 2 (1967): 352-78.
} 
and prosecutors, lack of proper investigation and lack of proper prosecution. Lack of evidence is due to the lack of will on the part of the witnesses to give evidence. Lack of will on the part of the witnesses is due to lack of support in ensuring they are properly protected. Even if a witness makes up his mind to give evidence against an accused, lack of proper investigation turns out to be a cause for the let off. In cases where the witness has a will to give evidence and the investigating agency has the prowess to investigate the case and unearth the hand behind the crime, the lack of prosecutorial skills leaves many lacunas and loopholes, which become instrumental to the failure of the case.

The same lacunas in the criminal justice system have also been highlighted by the learned Justice Ejaz Afzal Khan, a judge of the Supreme Court of Pakistan, in his dictum. He observed that a weak agency for the detection of crimes and inefficient machinery for its prosecution, inter alia are the main cause of delay in the disposal of criminal cases and a higher percentage of acquittal orders. Undoubtedly, that delay also occurs in the disposal of criminal cases on account of lapses on the part of some of the judicial officers, but the main reason seems to be heavy pendency, which warrants an increase in the strength of the courts. This has to be streamlined for a more efficient agency to detect the crimes. This includes the machinery for the prosecution and the courts in order to have a better deterrent effect on criminals. ${ }^{76}$ In actual fact, there are sufficient provisions in the Anti-Terrorism Act, 1997, which enable conviction on the basis of electronic or forensic evidence or such other evidences that may become available based on modern devices or techniques. Further, the Government, under section 19 (1) of the Anti-Terrorism Act, is also empowered to associate members of Intelligence Agencies and Armed Forces with investigations, but these provisions are rarely, if ever, used.

Therefore, the key to providing an enduring solution to the problem is by dealing with existing deficiencies, empowering and protecting the witnesses and judges and equipping the investigating agencies with the modern prosecutorial skills in order to make ensure that the actual terrorists are captured and convicted. Further, the delay in the disposition of cases can be eliminated to a larger extent through good court

\footnotetext{
${ }^{76}$ Rawalpindi District Bar Association v. Federation of Pakistan (PLD 2015 SC 401).
} 
management and not necessarily by the creation of a new court. In this context, the Supreme Court of Pakistan in its verdict in the case of Sh. Liaquat Hussain v. Federation of Pakistan, $1999^{77}$ also provided guidelines for a speedy and effective trial to combat terrorism within the purview of the existing criminal justice system. However, these guidelines, with regard to good court management, are rarely ever used.

Previously, The Justice Hamoodur Rehman Law Reform Commission Report, 1967-70 had also emphasized that in order to clear such back-log.

"It would be essential that the criminal justice system is reformed so as to be able to promptly punish the criminals and serve as a deterrent to would-be criminals. Such reform measures, however, should aim at improving and strengthening the current judicial system rather than substituting it with another. There is a scope within the system for the special procedure so as to put an end to acts of violence and terrorists' activities. Such measures, however, should be within the ambit of the Constitution, otherwise would be illegal".

Even if certain amendments are required in the criminal justice system, it is the responsibility of the government to make amendments in conformity with the constitutional provisions, which requires the trichotomy of powers, separation of judiciary from the executive and not by replacing it with parallel courts, controlled under the behest of the executive. In fact, a strong and independent judiciary that fairly and expeditiously adjudicates terrorism cases or national security offences is necessary for public confidence and it is an effective deterrent to terrorism and marks the distinction between a civilized society and total anarchy. If the judicial system is allowed to function without any let or hindrance and if it works well, the people can live their lives peacefully and enjoy freedom, security of their persons as well as rewards of their labours as guaranteed under the fundamental rights enunciated in the constitution.

${ }^{77}$ Sh. Liaqat Hussain and others v. Federation of Pakistan (PLD 1999 SC 504) 


\section{CONCLUSION}

An independent judicial organ is indispensable and must not be controlled by any other organs of the government in order to safeguard the due process of law. It is well settled that the right to a fair trial impliedly includes a public hearing by a competent, impartial, and independent tribunal. Furthermore, it is crystal clear on the face of preamble and Article 2-A of the Constitution of Pakistan that the rule of law, fundamental rights and independence of the judiciary shall be secured.

Civil liberties and military courts cannot be expected to exist side by side in accordance with the scheme of the Constitution of Pakistan. Military personnel, who preside over trials, are part of the executive, and it goes without saying that they are not part of the judiciary. And it has been repeatedly and categorically held by the superior courts of Pakistan that the administration of justice cannot be made subject to or controlled by the executive authorities. However, the Armed Forces can be called upon by the Federal Government under Article 245 of the Constitution to defend Pakistan against external aggression or threat of war but subject to the law and the actions of the Armed Forces, must be appropriate only to the restoration of peace and tranquillity. But it is not meant to confer them with judicial power. To exercise such power would be a violation of the principle of judicial independence as enunciated in Article 175(1) of the Constitution. They can certainly apprehend those culprits who disturb or threaten to disturb peace and tranquillity but such accused can only be tried by ordinary civil courts.

There is also an urgent need for reforms to be made to the procedural aspects of the Pakistani criminal justice system. The existing procedural criminal justice system of Pakistan remains the same from the $18^{\text {th }}$ century. Reforms are necessary in order to ensure speedy and fair trials that are in conformity with the spirit of the Constitution. Further, there is a need for reliance on new and more effective means of evidential tools and facilities, for example developing forensic evidence facilities, electronic or modern technological means of evidence, an effective association of investigating bodies with intelligence agencies and armed forces for effective prosecution of terrorist and sectarian cases.

On a final note, it is submitted that the best response to terrorism is to isolate, thwart, and defeat terrorists by the principles and rights that terrorists trample underfoot. Those accused of terrorist acts must be 
subjected to the due process of law, through an independent court and evidence-based convictions. If persons accused of terrorism are tried arbitrarily, there is a chance that the State will become a source of "terror" to the people of Pakistan. 